Meollis fuscilabris Muls.

Sunlight, Temperature $89^{\circ} \mathrm{F}$.

\begin{tabular}{|c|c|c|c|}
\hline A & & 5 inches, & 5 seconds \\
\hline B & & 6 inches, & 5 seconds \\
\hline C & & 3 inches, & 4 seconds \\
\hline$D$ & & 5 inches, & 4 seconds \\
\hline $\mathrm{E}$ & 7 feet, & & 2 minutes \\
\hline $\mathbf{F}$ & & 3 inches, & 4 seconds \\
\hline G & & 8 inches, & 3 seconds \\
\hline
\end{tabular}

Shade, Temperature $75^{\circ} \mathrm{F}$.

\begin{tabular}{llll} 
A & 12 feet, & 1 inch, & 9 minutes \\
B & & 6 inches, & \multicolumn{2}{l}{5 minutes } \\
C & 17 fect, & & 7 minutes \\
D & & 4 inches, & 5 seconds \\
E & 8 feet, & 2 inches, & 8 minutes \\
F & 1 foot, & 7 inches, & 4 minutes \\
G & 9 feet, & & 5 minutes
\end{tabular}

The averages for this species are 1 foot, 4 inches in the sunlight and 7 feet in the shade. Individuals which had climbed three or four feet in the shade after being moved to the sunlight, continued only a few inches more and then flew off. Of the three species, Megilla fuscilabris was the most active, being seemingly possessed of a nervous irritability.

All of the beetles were handled as little as possible and used only once.

The tables show that the length of time and especially the distance covered, were considerably shortened when the re-actions took place in sunlight and while the temperature was higher, yet beetles moved from the shade to sunlight flew away almost before they could have become sensible to the higher temperature.

Plant lice of course are usually found in shaded situations such as the undersides of leaves and Coccinellidæ undoubtedly hunt longer and over a greater distance in such situations.

It seems fair to conclude then, that other factors being equal, sunlight and possibly high temperatures shorten the distance covered during a geotropic response and also the time during which the beetle responds to such stimuli, thereby giving the beetle a greater chance to find food. Sunlight does not, however, influence the direction of locomotion or the negative geotropic position assumed by the beetle.

\title{
NOTES ON GYPONA OCTOLINEATA SAY
}

\author{
(Hemiptera, Jassidæ)
}

\section{By R. L. WEBSTER}

Not much concerning this common leaf-hopper, sometimes known as the "eight lined Gypona," appears in entomological literature. Outside of some observations by Fitch (1867) and later by Osborn and Ball (1897), very little has been written. While of no great economic importance, this species, with other leaf-hoppers, no doubt causes considerable injury in grass lands, as suggested by Osborn and 
Ball. As Fitch has said, however, the insects feed in a great variety of situations, with apparently little preference.

Occasional observations on this insect have been made by the writer in Iowa, and some new things have been learned. For that reason these notes are presented for publication, together with records of other writers, bringing so far as possible the knowledge of this species up to date. These notes are from the files of the entomological section of the Iowa Agricultural Experiment station at Ames.

Past History. This species was first described by Say (1825), who gave it the name Tettigonia octolineata. Subsequently it was placed in the genus Gypona. Fitch (1851) described Gypona favilineata, but Osborn and Ball (1897) consider that Fitch's species is only a variety of octolineata Say.

Distribution. Doctor Forbes has given as the distribution of this insect: Eastern United States, Canada to Texas. Van Duzee records the variety flavilineata collected by W. J. Palmer near Lake Temagami, Ontario. Lugger mentions the species as occurring in Minnesota and Uhler records it in Colorado.

Food Plants. Any list of the food plants of this ubiquitous species is necessarily incomplete, on account of its adaptability to so many different plants. Fitch listed the following: Dahlia, aster, oak, walnut, beech, maple, birch, willow and dogwood. Other records are blackberry (Lugger) and sugar beet (Forbes). Osborn and Ball found that the insect "occurred upon the wild grasses of woodlands especially." In the insectary at Ames the nymphs and adults lived on apple shoots readily.

Life History. Generations. Osborn and Ball (1897) have shown that there are in Iowa two generations of this insect. In 1909 in the insectary two generations were observed, for second brood nymphs were reared from eggs deposited by first brood adults. The insect winters in the egg stage and the eggs are placed singly in small pouches in the bark of apple and probably of other trees.

Osborn and Ball said that the first brood nymphs (half to full grown) were abundant in Iowa from mid-June to mid-July; the adults from the first of July to the middle of August. The writer's records are generally earlier than these dates. Practically all of the notes of the writer refer to the first generation.

According to Osborn and Ball the second brood larvæ appear in late August and September; the adults in September and October.

The adults of the first generation are of the flavilineata type, while those of the second are usually of the octolineata type, according to the observations of Osborn and Ball. The adults (all first brood) reared in the insectary by the writer, were all of the flavilineata type. 
The Egg. Eggs of this species were found deposited in the bark of young apple trees, as the following notes from insectary records show.

In the spring of 1909 a number of young Jonathan apple trees, sent from Shenandoah, Iowa, were set out in the insectary for experimental use. In the bark of one of these trees were two egg pouches, similar to those figured by Riley (1892) as egg pouches of the Membracid, Ceresa taurina Fitch. These two eggs hatched, but the nymphs were overlooked until May 31, when they were over half grown. Some of these same nymphs were found on other young Jonathan trees in the insectary at this time. The two nymphs from the one tree were kept in a separate cage on a young apple tree, and on June 9 they became adult. The two happened to be male and female, and were found in copulation at this time. The species was then determined as Gypona octolineala, variety flavilineata.

On June 15 in this cage I found a single egg deposited openly on a leaf, and also a number of egg slits in the bark of the young apple tree. The single egg in the open was apparently accidentally deposited there. This egg was cylindrical, white, $1.63 \mathrm{~mm}$. long and $.32 \mathrm{~mm}$. broad. One end of the egg was slightly more rotund that the other, which tapered a little more.

These egg slits were, of course, similar to those in the apple bark from which the parent Jassids had come. On subsequent days in this cage more eggs were deposited, until 34 in all were counted in the bark. These eggs were placed usually at random over the bark; in one instance four were placed in a row, one below the other, and slightly to the left. These last apparently were deposited at one time.

On July 3, 18 days after the eggs were first seen, the young nymphs appeared in this cage. These nymphs lived for about two weeks, but finally all of them died, apparently having been killed by some spiders that had gotten into the cage.

At Shenandoah in the spring of 1908 , and again in 1909, I noticed egg pouches similar to those described above, in apple nursery stock in some abundance. This was in the same nursery from which the young Jonathan trees, previously mentioned, had come. The same kind of eggs were also common on Carolina poplar nursery trees, where from 6 to 12 punctures in a row were often found, although from 6 to 9 was the usual number.

These eggs found at Shenandoah were like those deposited in the apple bark in the insectary, except that there was a black mark present on the egg at the slit. This mark shows on the egg itself, after being dissected from the bark, as well as through the slit in its normal position. In the eggs deposited in the insectary cage in June, these black 
marks were not found. I think, however, that both kinds were made by the same species.

Twice I have run across eggs of this kind in the skin of apples, once in 1908 and again in 1909. In 1909 (Journ. Econ. Ent.) I described the eggs found the fall before, referring them doubtfully to Ceresa taurina Fitch. The work of Hodgkiss (1910), however, has shown that the eggs of Ceresa taurina are placed in a quite different situation, and my more recent observations show that the eggs of Gypona octolineata are similar to, and probably the same as, the eggs found in the skin of the apple.

No blackened portion of the egg is mentioned in my notes of November, 1908, but in November, 1909, when similar eggs were found in a Ben Davis apple, the black mark on the egg at the slit was quite distinct.

Jassid eggs of this description have been referred to two species of Membracids, first to Ceresa bubalus Fabr., by Riley (1873) and later by the same writer (1892) to Ceresa taurina Fitch. Hodgkiss (1910) has shown that the eggs of Ceresa taurina are deposited in the buds of apple trees, and refers the egg pouches figured by Riley to some of the large leaf-hoppers, naming Gypona cana Burm., and Gypona octolineata Say.

An excellent illustration of these eggs may be found in the Pennsylvania Zoölogical Bulletin, vol. 5. No. 3. plate ix., drawn by W. R. Walton. Here the eggs are wrongly referred to Ceresa bubalus, in spite of Riley's later correction (1892).

The Nymphs. I have twice observed nymphs hatching from eggs which were probably of this species. At any rate I could not distinguish any differences that would separate them. At Shenandoah May 10,1909 , I found a nymph just emerging from an egg deposited in the bark of a Carolina poplar tree. Again at Burlington, Iowa,- April 15,1910 (a very early spring) I found a nymph emerging from an egg placed in the bark of a crabapple tree. These nymphs were both pale orange in color, with long antennæ, reaching beyond the tip of the abdomen. They were also pale along the median dorsal line.

The following description of the larva is taken from Osborn and Ball. "The larvæ very strongly resemble the adults. The head is abruptly narrowed in front of the eyes but projected centrally. The antennæ are very long, the basal joint nearly as long as the vertex, while the bristle reaches to the middle of the abdomen. The abdomen is long, rather slender, color green."

In the insectary cages the larv were found usually feeding along the green stems of apple twigs, or in the axils of the leaves.

The Adults. I can add nothing to previous accounts concerning the adult insects. 


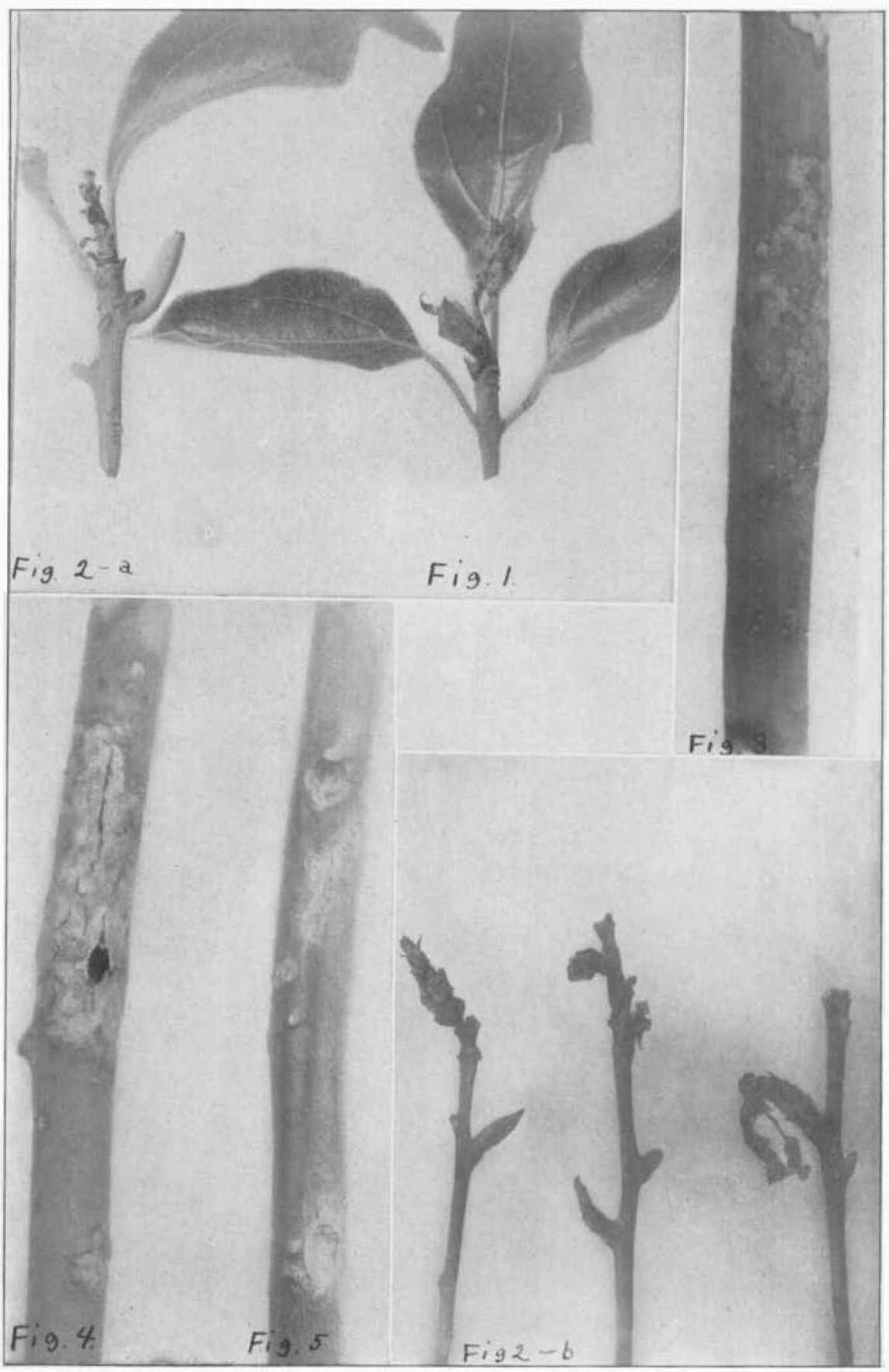

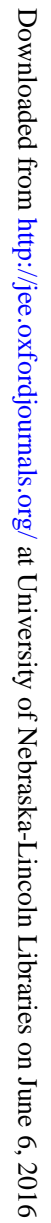

Work of Cryptothrips on Orange 


\section{BIBLIOGRAPHY}

1825. Say, Thomas.-Acad. Nat. Sci. Phila. vol. iv. p. 340. Original description. Inhabits Missouri.

1851. Futch, Asa.-Homop. N. Y. State Cab. p. 57. Describes Gypona flavilineala. 1867. Firch, AsA.-Trans. N. Y. State Agr. Soc. vol. xxvii. p. 893. (12th Rep.) General account of Gypona octolineata and Gypona flavilineata, which are considered separate.

1873. Riney, C. V.-5th Rep. Ins. Mo. p. 121. Gives a figure of egg punctures in apple bark, then supposed to be those of Ceresa bubalus Fabr.

1892. Riley, C. V.-Proc. Ent. Soc. Wash. vol. iii. p. 88. Says that figure of egg pouches given as those of Ceresa bubalus (1873) are those of an allied Membracid, Ceresa taurina Fitch.

1897. Osborn, Herbert and Bald, E. D.-Iowa Agr. Exp. Sta. Bul. 34. p. 616. Life history notes. The forms octolineata and flavilineata are considered as the same species.

1900. Lugger, Oтto.-6th Rep. Minn. Ent. p. 135. Affecting blackberry in Minnesota.

1900. Forbes, S. A.-21 Rep. State Ent. Ill. p. 72. Affecting sugar beet in Illinois.

1907. Surface, H. A.-Pa. Dept. Agr. Zoöl. Bul. vol. 5. no. 3. Plate IX. Gives an excellent figure of Gypona egg punctures in bark, but refers these to Ceresa bubalus.

1909. Webster, R. L.-Journ. Econ. Ent. vol. ii. p. 193. Mentions finding eggs in an apple, possibly those of Ceresa taurina.

1910. Hodgkiss, H. E.-N. Y. Agr. Exp. Sta. Tech. Bul. 17. p. 100. Says that the egg pouches figured by Riley as Ceresa are those made by species of Gypona.

\section{AN UNUSUAL TYPE OF INJURY DUE TO A THRIPS}

By J. R. Watson, Gainesville, Fla.

In the Entomological News for February, 1912, the writer described an apparently new species of thrips (Cryptothrips foridensis), which was attacking camphor trees on the extensive plantation of the Satsuma Company at Satsuma, Florida. Since then some additional studies and a personal inspection of the work of the insect in the field have been made. These studies have discovered a type of injury so unusual for a thrip as to suggest that it might not be without interest to the readers of the Journal of Economic Entomology.

In the beginning of the infestation of the camphor tree, the eggs are laid between the scales of the terminal bud. If the bud has commenced to develop when the eggs hatch, the larvæ first attack the new growth. If there are but a few of the larva on each bud, there will result a blackening and deforming of one side of the young leaves (Plate 11, figure 1). If there are more of the larvæ, the developing bud will be killed outright, (Plate 11, figure 2). The insects then attack the younger twigs where they feed in groups, the yellow larvæ 